\title{
Clinical heterogeneity can hamper the diagnosis of patients with ZAP70 deficiency
}

\author{
Tuba Turul • Ilhan Tezcan • Hasibe Artac • \\ Sandra de Bruin-Versteeg • Barbara H. Barendregt • \\ Ismail Reisli • Ozden Sanal • \\ Jacques J. M. van Dongen • Mirjam van der Burg
}

Received: 17 December 2007 / Accepted: 10 March 2008 / Published online: 29 May 2008

(C) The Author(s) 2008

\begin{abstract}
One of the severe combined immunodeficiencies (SCIDs), which is caused by a genetic defect in the signal transduction pathways involved in T-cell activation, is the ZAP70 deficiency. Mutations in ZAP70 lead to both abnormal thymic development and defective T-cell receptor (TCR) signaling of peripheral T-cells. In contrast to the lymphopenia in most SCID patients, ZAP70-deficient patients have lymphocytosis, despite the selective absence of $\mathrm{CD}^{+} \mathrm{T}$-cells. The clinical presentation is usually before 2 years of age with typical findings of SCID. Here, we present three new ZAP70-deficient patients who vary in their clinical presentation. One of the ZAP70-deficient patients presented as a classical SCID, the second patient presented as a healthy looking wheezy infant, whereas the third patient came to clinical attention for the eczematous
\end{abstract}

T. Turul · S. de Bruin-Versteeg · J. J. M. van Dongen •

M. van der Burg $(\bowtie)$

Department of Immunology, Erasmus MC,

University Medical Center Rotterdam,

Dr. Molewaterplein 50,

3015 GE Rotterdam, The Netherlands

e-mail: m.vanderburg@erasmusmc.nl

T. Turul $\cdot$ I. Tezcan $\cdot$ O. Sanal

Department of Immunology,

Hacettepe University Children's Hospital,

Ankara, Turkey

H. Artac $\cdot$ I. Reisli

Department of Pediatric Immunology and Allergy,

Meram Medical Faculty, Selçuk University,

Konya, Turkey

B. H. Barendregt

Department of Pediatrics, Erasmus MC,

Sophia Children's Hospital,

Rotterdam, The Netherlands skin lesions simulating atopic dermatitis with eosinophilia and elevated immunoglobulin E (IgE), similar to the Omenn syndrome. This study illustrates that awareness of the clinical heterogeneity of ZAP70 deficiency is of utmost importance for making a fast and accurate diagnosis, which will contribute to the improvement of the adequate treatment of this severe immunodeficiency.

Keywords Severe combined immunodeficiency . ZAP70 . T-cell receptor signaling $\cdot \mathrm{T}$-cells
Abbreviations
SCID Severe combined immunodeficiency
TCR T-cell receptor
ZAP70 ל-chain-associated protein kinase of $70 \mathrm{kDa}$
Ig Immunoglobulin
HSCT Hematopoietic stem cell transplantation

\section{Introduction}

Severe combined immunodeficiency (SCID) is a primary immunodeficiency that is characterized by severely reduced numbers or the total absence of functional T-cells, which, in turn, results in the absence of an adaptive immune response, including strongly reduced or virtually absent serum immunoglobulin (Ig) levels [4]. Despite the presence of various underlying genetic defects, patients usually have a common clinical picture with opportunistic infections, leading to failure to thrive. The overall incidence is estimated to be 1 in 50,000 to 75,000 births. Infants with SCID can be lymphopenic, which aids the early diagnosis $[2,3]$. Defects in any one of the 23 genes inherited either in an autosomal recessive or an X-linked manner can cause a combined T- and B-cell immunodeficiency with a well- 
defined immunophenotypical and clinical picture [10, 18]. The various forms of SCID can be classified according to their lymphocyte phenotype, depending on the presence or absence of T-, B-, or NK cells, namely, T-B+NK-, T-B+NK+, T-B-NK+, and T-B-NK- SCIDs [3]. Among T-B+NK+ SCIDs, IL7R $\alpha$ deficiency and deficiencies in the $\operatorname{CD} 3 \gamma$, $\mathrm{CD} 3 \delta, \mathrm{CD} \varepsilon$, or $\mathrm{CD} 3 \zeta$ are the known genetic defects [9]. Genetic defects giving rise to the absence of specific T-cell subsets can be due to a defect in the signal transduction pathways involved in T-cell activation. This may result, clinically and immunophenotypically, in heterogeneous presentations, reflecting highly variable defects ranging from severe cellular dysfunction to negligible dysfunction. Defects can involve MHC class I and class II, Lck, ZAP70 ( $\zeta$-chain-associated protein kinase of $70 \mathrm{kDa}$ ), and CD8 $\alpha$ molecules $[1,5,11,13]$. Following antigen binding to the T-cell receptor (TCR) complex, signals are propagated to the nucleus via nonreceptor cytoplasmic protein tyrosine kinases (PTKs), namely, Lck and ZAP70 (Fig. 1) [16]. SCIDs resulting from ZAP70 deficiency was first described in 1994, and is characterized by lymphocytosis, the selective absence of $\mathrm{CD} 8^{+} \mathrm{T}$-cells in peripheral blood, and profoundly defective signal transduction through the TCR$\mathrm{CD} 3$ complex on the remaining $\mathrm{CD}^{+}{ }^{+}$T-cells [7]. To date, 15 cases of ZAP70 deficiency have been reported [1, 7, 14, $15,19]$. The patients usually present before 2 years of age with a history of recurrent bacterial, viral and opportunistic infections, diarrhea, and failure to thrive, thereby, meeting the criteria for the diagnosis of SCID [7]. Here, we present three cases of ZAP70 deficiency that illustrate the striking heterogeneity in the clinical presentation of the disease.

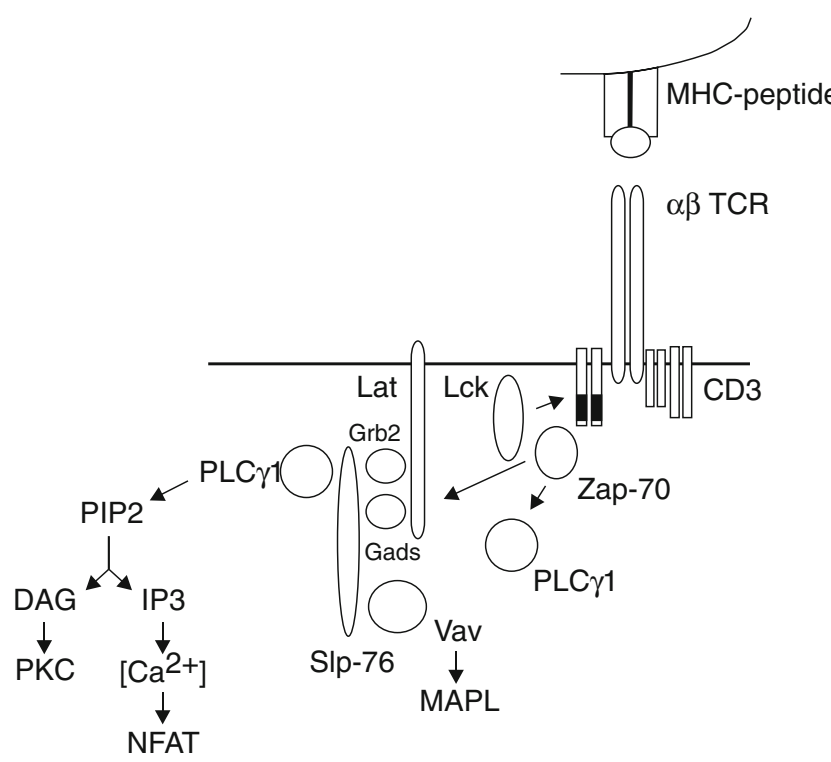

Fig. 1 Schematic representation of T-cell receptor (TCR) signaling [16]

\section{Materials and methods}

Flow cytometric immunophenotyping

The cell surface expression of CD3, CD4, and CD8 was assayed on whole-blood samples by flow cytometry using a FACSCalibur (BD Biosciences, San Jose, CA). Patient material was obtained according to the medical ethics guidelines of Hacettepe University Children's Hospital, the Meram Medical Faculty of the Selçuk University, and Erasmus MC. Antibodies were obtained from BD Biosciences. ZAP70 surface expression was determined using the monoclonal antibody 1E7.2 (eBioscience, San Diego, CA).

Molecular analysis of the ZAP70 gene

Polymerase chain reaction (PCR) was performed to amplify the ZAP70 exons (MIM 176947; NCBI L05148); the primer sequences are available upon request. In each $25 \mu \mathrm{l}$ of PCR reaction, 5 pmol of $5^{\prime}$ and $3^{\prime}$ oligonucleotides, $25 \mathrm{ng}$ DNA, and $0.5 \mathrm{u}$ AmpliTaqGold ${ }^{\mathrm{TM}}$ polymerase template and buffer PCR System (Applied Biosystems, Roche Molecular Systems Inc., Branchburg, NJ) were used. PCR products were used directly for sequencing with BigDye Terminator mix (Applied Biosystems) and $3.3 \mathrm{pmol}$ $5^{\prime}$ or $3^{\prime}$ primers. All sequencing was performed on an ABI Prism 3100 fluorescent sequencer (Applied Biosystems).

$\mathrm{Ca}^{2+}$ flux assay

Thawed peripheral blood mononuclear cells $\left(1 \times 10^{6}\right)$ were incubated with $6 \mu \mathrm{g} / \mathrm{ml}$ of calcium-sensitive fluorescent dye Indo-1 (Molecular Probes) to evaluate the calcium fluxes after stimulation. The levels of free intracellular calcium were measured in $\mathrm{CD}^{+}$T-cells with a FACSVantage sorter (BD Biosciences) before and after stimulation with $12.5 \mu \mathrm{g} / \mathrm{ml}$ of functional-grade purified OKT3 CD3 antibody (eBioscience). Subsequently, $2 \mu \mathrm{g} / \mathrm{ml}$ of ionomycin (Molecular Probes) was added to control for the intracellular loading of Indo-1, as previously described [21].

\section{Case reports}

Patient 1

The first patient (ZAP70-1) was admitted to the hospital at the age of 5 months suffering from lower respiratory tract infection with significant respiratory distress. She experienced recurrent lower respiratory tract infections, usually without fever, but with accompanying wheezing beginning at 4 months of age. She did not have recurrent oral candidiasis nor any sign of failure to thrive. Instead, on admission, she 
was a well-developed baby with a weight and height at the 90th percentile. She had visible tonsils and palpable lymph nodes. In Fig. 2, the family tree of the case is depicted.

Chest X-ray showed hyperinflation with interstitial infiltration suggestive for a viral infection. Bronchoalveolar lavage fluid examination excluded Pneumocystis jiroveci, cytomegalovirus (CMV), Mycoplasma pneumoniae, and Mycobacterium species. As shown in Table 1, the immunological findings were suggestive for a combined immunodeficiency (CID), and the low $\mathrm{CD} 8^{+} \mathrm{T}$-cell count and the normal response to phorbol myristate acetate (PMA) and ionomycin was consistent with a ZAP70 defect.

Patient 2

Patient 2 (ZAP70-2) had experienced recurrent gastroenteritis, lower respiratory tract infections, and oral moniliasis accompanied by failure to thrive, frequently requiring hospitalization since 3 months of age (Table 1).

On admission at the age of 13 months, both her weight and height were below the third percentile. She had visible tonsils and palpable lymph nodes. A scar tissue on the left deltoid formed following a BCG vaccination was visible. There were multiple ulcerative perianal and genital lesions. Her family tree is shown in Fig. 2.

Bone marrow aspiration performed during follow-up because of the development of hepatomegaly and bicytopenia showed hemophagocytosis. Viral serology, PCR studies, and bacterial cultures could not define an etiologic agent. The patient was considered to have secondary hemophagocytic syndrome and was put on immunosuppressive therapy. The $\mathrm{CD} 8^{+} \mathrm{T}$-cell count was strongly reduced (Table 1). The patient's clinical status deteriorated progressively and she died of multiorgan
Fig. 2 Family trees of the three patients showing the consanguinity of the parents
Patient 1

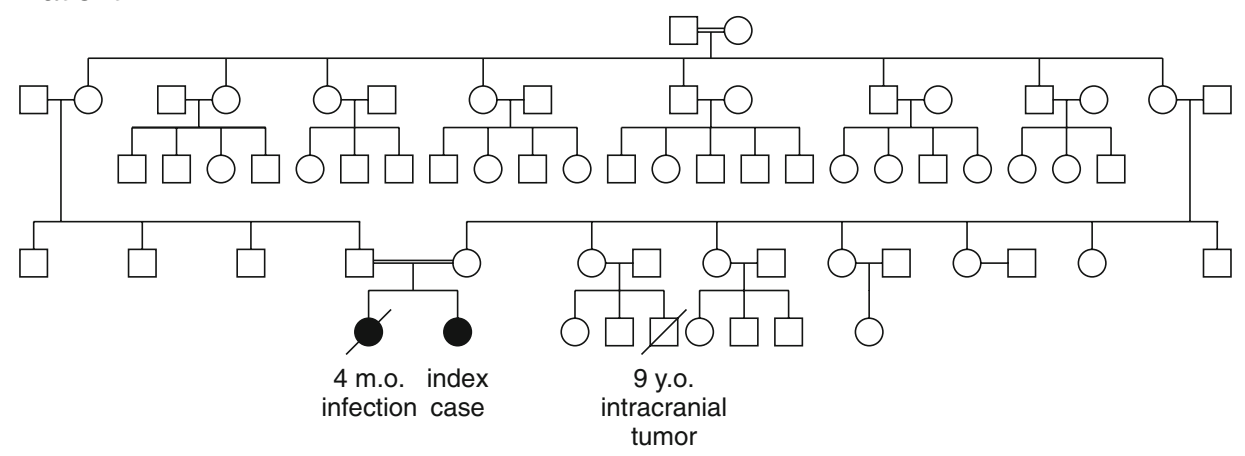

Patient 2

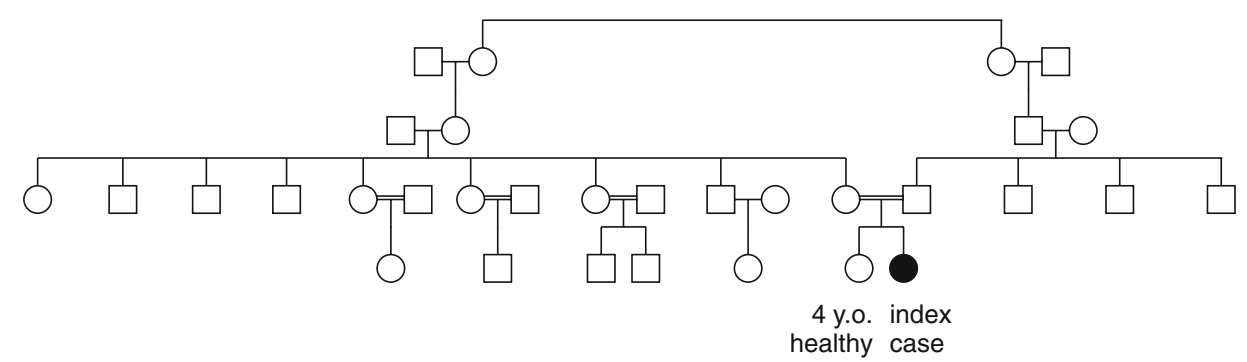

Patient 3

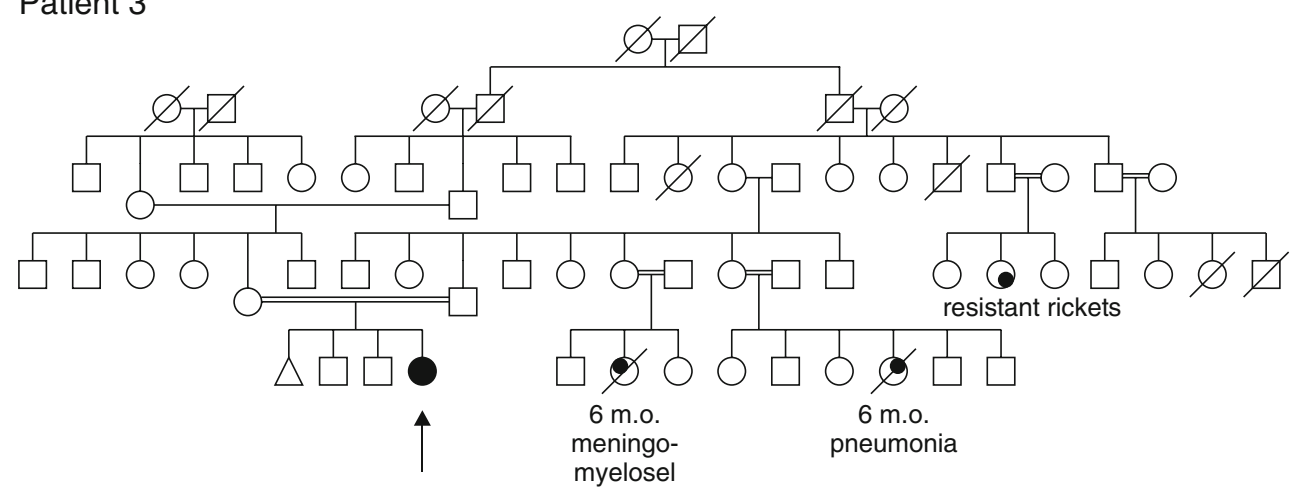


Table 1 Clinical characteristics and immunological parameters of the three patients with ZAP70 deficiency from unrelated families of Turkish origin

\begin{tabular}{|c|c|c|c|}
\hline & Patient 1 & Patient 2 & Patient 3 \\
\hline $\begin{array}{l}\text { Age of onset } \\
\text { (months) }\end{array}$ & 4 & 3 & 2 \\
\hline $\begin{array}{l}\text { Age of diagnosis } \\
\text { (months) }\end{array}$ & 5 & 13 & 11 \\
\hline Consanguinity & First degree & Second degree & Second degree \\
\hline Family history & $\begin{array}{l}\text { A 3-month-old male } \\
\text { sibling died of LRTI }\end{array}$ & Insignificant & $\begin{array}{l}\text { A 2-month-old female cousin } \\
\text { died of unknown reason }\end{array}$ \\
\hline Clinical picture & $\begin{array}{l}\text { Recurrent LRTI (wheezing) } \\
\text { Tonsillary tissue }(+)\end{array}$ & $\begin{array}{l}\text { Recurrent LRTI } \\
\text { Recurrent gastroenteritis } \\
\text { Oral moniliasis } \\
\text { Perianal and perineal ulcers } \\
\text { Tonsillary tissue }(+) \\
\text { Bilateral inguinal lymphadenopathy }\end{array}$ & $\begin{array}{l}\text { Recurrent LRTI } \\
\text { Oral moniliasis } \\
\text { Disseminated BCG infection } \\
\text { Generalized lymphadenopathies } \\
\text { Tonsillary tissue }(-)\end{array}$ \\
\hline $\operatorname{ALC}\left(\times 10^{9} / \mathrm{L}\right)$ & 5.3 & 2.8 & 17.1 \\
\hline $\mathrm{CD} 3 \% / \#\left(\times 10^{9} / \mathrm{L}\right)$ & $78.9 / 4.2$ & $59.6 / 1.7$ & $45.7 / 7.8$ \\
\hline $\mathrm{CD} 4 \% / \#\left(\times 10^{9} / \mathrm{L}\right)$ & $76.3 / 4$ & $58.5 / 1.7$ & $37.4 / 6.4$ \\
\hline $\mathrm{CD} 8 \% / \#\left(\times 10^{9} / \mathrm{L}\right)$ & $1 / 0.05$ & $0.8 / 0.02$ & $1.2 / 0.2$ \\
\hline $\operatorname{IgA}(\mathrm{mg} / \mathrm{dl})$ & 118 & 23 & 86 \\
\hline $\operatorname{IgM}(\mathrm{mg} / \mathrm{dl})$ & 49 & 179 & 72 \\
\hline $\operatorname{IgG}(\mathrm{mg} / \mathrm{dl})$ & 203 & 785 & 560 \\
\hline Isohemagglutinin titers & Anti B 1/8 (+) & Anti A (-), Anti B (-) & Anti A $1 / 4$ \\
\hline Blood groups & A & 0 & $\mathrm{~B}$ \\
\hline Anti $\mathrm{Hbs}$ & $60 \mu / 1$ & (-) (after 2nd dose) & $(+)$ \\
\hline Anti polio titers & $\begin{array}{l}\text { PT1 }(-)^{*} \\
\text { PT2 }(-) \\
\text { PT3 }(-)\end{array}$ & Not tested & Not tested \\
\hline \multirow[t]{2}{*}{$\begin{array}{l}\text { In vitro lymphocyte } \\
\text { proliferation } \\
\text { test/ }(\mathrm{SI})^{* *}\end{array}$} & PHA: $28.4 / 85.8$ & PHA: 22.2/57.9 & PHA: $23 \%$ \\
\hline & $\begin{array}{l}\text { ConA: } 4.3 / 38.4 \\
\text { PMA+I: } 35.8 / 15.9\end{array}$ & $\begin{array}{l}\text { ConA: } 10.6 / 73.5 \\
\text { PMA+I: } 49 / 26\end{array}$ & Anti CD3: $10 \%$ \\
\hline Clinical outcome & $\begin{array}{l}\text { Well with IVIG and } \\
\text { prophylactic antibiotics, } \\
\text { HSCT has not been } \\
\text { performed yet }\end{array}$ & $\begin{array}{l}\text { Died of multiorgan failure } \\
\text { due to secondary } \\
\text { hemophagocytic syndrome } \\
\text { developed during follow-up }\end{array}$ & $\begin{array}{l}\text { Still under antituberculous } \\
\text { therapy with clinical } \\
\text { improvement, waiting } \\
\text { for HSCT }\end{array}$ \\
\hline
\end{tabular}

*Undetectable

**Patient and control values

$\mathrm{SI}=$ stimulation index; PMA+I=phorbol myristate acetate+ionomycin; HSCT=hematopoietic stem cell transplantation; LRTI=lower respiratory tract infection; PT=polio titer; IVIG=intravenous immunoglobulin

failure one month before HLA haploidentical transplantation could be done.

\section{Patient 3}

Patient 3 (ZAP70-3) had experienced recurrent pneumonia and oral moniliasis since 2 months of age. At 6 months of age, she developed widespread exfoliative dermatitis and subcutaneous nodules (Fig. 3).

Physical examination on admission at 11 months of age showed that her weight, height, and head circumference were below the third percentile. She had widespread xerosis and ichthyosis, together with subcutaneous nodules. No tonsillary tissue was visible. There were bilateral fine rales on auscultation of the lungs and she had hepatomegaly and generalized lymphadenopathies of $1-2 \mathrm{~cm}$ in size. Computed tomography of the thorax revealed the absence of thymus, pneumonic consolidation of the right upper lobe, and a lymphadenopathy located in the azygoesophageal recess. In Fig. 2, her family tree is shown. The laboratory findings are shown in Table 1. Additionally, chimerism analysis ruled out the presence of maternal cells.

With the diagnosis of SCID, the patient was put on intravenous immunoglobulin (IVIG), antibacterial, antifun- 


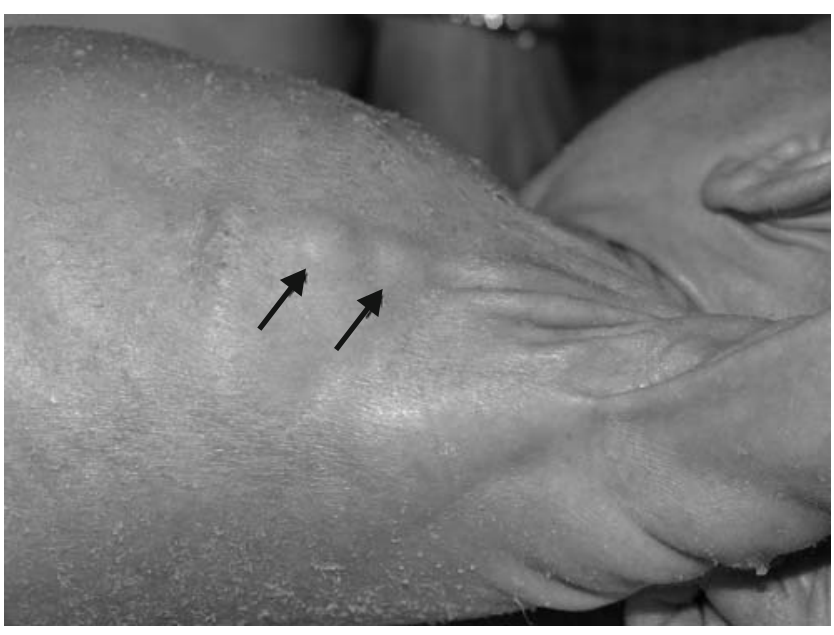

Fig. 3 Patient 3 presented with a marked failure to thrive, exfoliative dermatitis, and subcutaneous nodules (indicated by the arrows)

gal, and antiprotozoal prophylaxis. During follow-up, splenomegaly and several new subcutaneous nodules developed located on the tibia, gluteal region, anterior chest wall, and the arm, including the left deltoid region where the BCG vaccine scar was located. Two separate biopsy specimens obtained from two of the nodules revealed granulomatous inflammation without caseification. No acid-resistant basil (ARB) was visible and the cultures were negative for Mycobacterium species. Since both the nodules and splenomegaly regressed by a multidrug regimen (isoniazide +rifampisin+pyrazinamide+streptomycin), she was considered to have mycobacteria (probably BCG) infection. She developed generalized erythrodermia with associative eosinophilia and an elevation in IgE levels presenting as Omenn phenotype. The patient is currently being prepared for an HLA identical hematopoietic stem cell transplantation (HSCT) from one of the siblings.

\section{Results}

Flow cytometric analysis of the peripheral blood

Flow cytometric analysis of the peripheral blood was performed for all three patients. Patients 1 and 2 had normal lymphocyte counts, but patient 3 had lymphocytosis. However, there was a severe reduction in the absolute number of $\mathrm{CD}^{+}{ }^{+}$-cells and almost all $\mathrm{CD} 3^{+} \mathrm{T}$-lymphocytes were CD4-positive. $\mathrm{CD} 8^{+}$T-cells were found to be $1 \%\left(0.05 \times 10^{9}\right), 0.8 \%\left(0.02 \times 10^{9}\right)$, and $1.2 \%\left(0.2 \times 10^{9}\right)$ in patients 1,2 , and 3 , respectively. This phenotypical finding led us to evaluate the expression of ZAP70 protein in Tlymphocytes. All three patients did not have ZAP70 protein expression on their remaining $\mathrm{CD}^{+}{ }^{+} \mathrm{T}$-lymphocytes and further evaluation of the parents of patients 1 and 2 revealed an intermediate ZAP70 expression as compared to healthy control cells (Fig. 4).

Molecular analysis of the ZAP70 gene

Direct fluorescent sequencing of the ZAP70 gene of all three patients revealed homozygous mutations in the ZAP70 gene (Fig. 5). Patient 1 had a homozygous point mutation (c.1520C $>\mathrm{T}$ ), resulting in an amino acid replacement (p.Ala507Val) in the tyrosine kinase domain. The parents were both carriers of the mutation. In patient 2 , the identified homozygous mutation $(\mathrm{c} .1010 \mathrm{~T}>\mathrm{G})$ resulted in an amino acid substitution (p.Leu337Arg), which is the amino acid preceding the tyrosine kinase domain. The mutation in patient 3 concerned a homozygous mutation (c.1690T $>$ C), also affecting the tyrosine kinase domain (p. Cys564Arg). The mutation identified in patient 1 has been described before [21], whereas the other two mutations concern new mutations.

\section{Calcium flux study}

To assess directly the signaling competence of $\mathrm{CD}^{+}$cells, we measured the mobilization of intracellular $\mathrm{Ca}^{2+}$ in the thawed PBMC of patients 1 and 3. OKT3 antibody was used to stimulate the classical TCR signaling pathway, leading to the intracellular mobilization of $\mathrm{Ca}^{2+}$. This antibody induces TCR cross-linking, but failed to mobilize significant amounts of intracellular $\mathrm{Ca}^{2+}$ from any of the patient's T-cells, whereas biochemical stimulation with ionomycin could elaborate $\mathrm{Ca}^{2+}$ flux in all of the patient cells (data not shown).

\section{Discussion}

Here, we present three patients from unrelated families with severe reduction in $\mathrm{CD}^{+}$T-cells and the presence of normal counts of nonfunctional $\mathrm{CD} 4^{+} \mathrm{T}$-cells. These cells are defective in TCR activation, as demonstrated both by the absence of proliferative response to mitogens and impaired $\mathrm{Ca}^{2+}$ flux to CD3 (OKT3) stimulation. All three patients had missense mutations in the ZAP70 gene, leading to the absence of protein expression.

Although all three mutations lead to the total absence of ZAP70 protein expression, the clinical pictures of the patients showed a striking heterogeneity, discarding a straightforward genotype-phenotype relationship. The age of onset of the disease of the three patients was before six months of age, which is quite typical for SCID. In the literature, the age of onset is variable, however, being always before 12 months of age. Patients 2 and 3 had a quite severe phenotypes not compatible with life and 


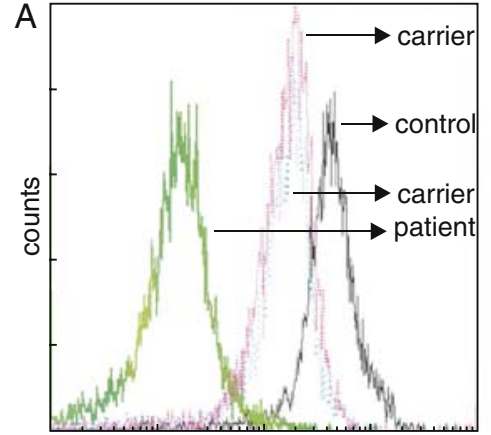

ZAP70-PE

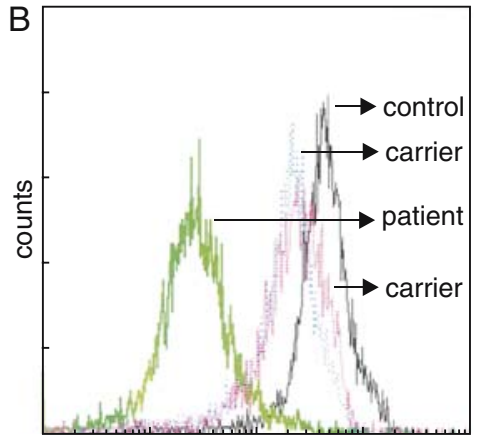

ZAP70-PE

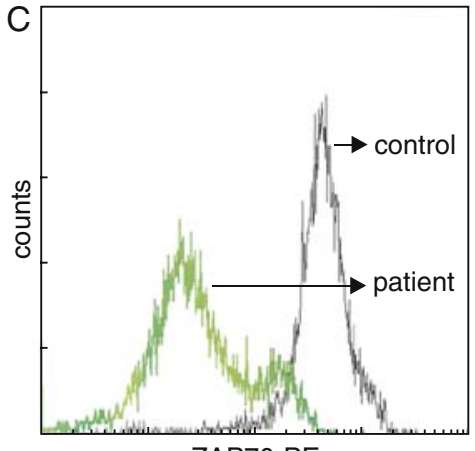

ZAP70-PE
Fig. 4 Flow cytometric analysis of ZAP70 expression of patients 1, 2, and 3, the parents of patients 1 and 2, and healthy controls. All three patients had a strongly reduced level of ZAP70 expression as compared to the healthy controls. The parents of patients 1 and 2 had intermediate ZAP70 expression

skin changes in ZAP70-deficient patients came from Toyabe et al., who found that T-cells in these patients had the capacity to induce antigen-specific IgE production from B cells in response to TCR stimulation [20].

The humoral immunity is also variably affected among the ZAP70 patients, some having severe hypogammaglobulinemia requiring IVIG, some having normal levels of immunoglobulins, as in patient 2 , or even hypergammaglobulinemia $[1,6,8,17]$. In sporadic cases, specific antibody production can be preserved $[17,19]$. Only in patient 1 was the protein antigen response selectively preserved for hepatitis B, whereas this was not the case in the two other patients.

In conclusion, this study illustrates the clinical heterogeneity of patients with a ZAP70 deficiency. These patients can present as classical SCID, but, sometimes, they present as healthy looking wheezy infants or can come to clinical attention for the eczematous skin lesions simulating atopic dermatitis with eosinophilia and elevated IgE similar to the Omenn syndrome. Awareness of the clinical heterogeneity of ZAP70 deficiency is of utmost importance for making a fast and accurate diagnosis, which will contribute to the improvement of the adequate treatment of this severe immunodeficiency.
Fig. 5 Sequence analysis of the ZAP70 gene revealed homozygous point mutations in all three patients, leading to amino acid replacements in or just next to the protein kinase domain

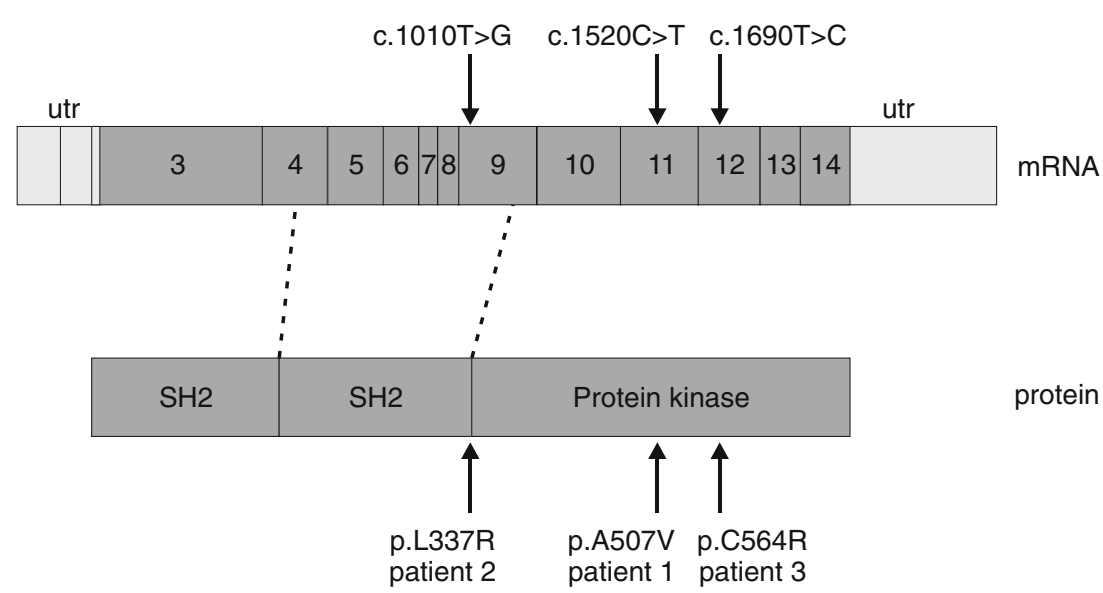


Acknowledgements The authors thank Mrs. Marieke Comans-Bitter for her preparation of the figures. This study has been supported by an ESID Scholarship of the European Society for Immunodeficiencies (TT) and by a Health Care Innovation grant (Zorgvernieuwingsproject) (JJMvD, MvdB).

Open Access This article is distributed under the terms of the Creative Commons Attribution Noncommercial License which permits any noncommercial use, distribution, and reproduction in any medium, provided the original author(s) and source are credited.

\section{References}

1. Arpaia E, Shahar M, Dadi H, Cohen A, Roifman CM (1994) Defective $T$ cell receptor signaling and CD8+ thymic selection in humans lacking zap-70 kinase. Cell 76:947-958

2. Buckley RH, Schiff RI, Schiff SE, Markert L, Williams LW, Harville TO, Roberts JL, Puck JM (1997) Human severe combined immunodeficiency: genetic, phenotypic, and functional diversity in one hundred eight infants. J Pediatr 130:378-387

3. Buckley RH (2002) Primary immunodeficiency diseases: dissectors of the immune system. Immunol Rev 185:206-219

4. Cunningham-Rundles C, Ponda PP (2005) Molecular defects in Tand B-cell primary immunodeficiency diseases. Nat Rev Immunol 5:880-892

5. de la Calle-Martin O, Hernandez M, Ordi J, Casamitjana N, Arostegui JI, Caragol I, Ferrando M, Labrador M, RodriguezSanchez JL, Espanol T (2001) Familial CD8 deficiency due to a mutation in the CD8 alpha gene. J Clin Invest 108:117-123

6. Elder ME, Lin D, Clever J, Chan AC, Hope TJ, Weiss A, Parslow TG (1994) Human severe combined immunodeficiency due to a defect in ZAP-70, a T cell tyrosine kinase. Science 264:1596-1599

7. Elder ME (1998) ZAP-70 and defects of T-cell receptor signaling. Semin Hematol 35:310-320

8. Elder ME, Skoda-Smith S, Kadlecek TA, Wang F, Wu J, Weiss A (2001) Distinct T cell developmental consequences in humans and mice expressing identical mutations in the DLAARN motif of ZAP-70. J Immunol 166:656-661

9. Fischer A, de Saint Basile G, Le Deist F (2005) CD3 deficiencies. Curr Opin Allergy Clin Immunol 5:491-495

10. Geha RS, Notarangelo LD, Casanova JL, Chapel H, Conley ME, Fischer A, Hammarström L, Nonoyama S, Ochs HD, Puck JM, Roifman C, Seger R, Wedgwood J (2007) Primary immunodeficiency diseases: an update from the International Union of
Immunological Societies Primary Immunodeficiency Diseases Classification Committee. J Allergy Clin Immunol 120:776-794

11. Goldman FD, Ballas ZK, Schutte BC, Kemp J, Hollenback C, Noraz N, Taylor N (1998) Defective expression of p56lck in an infant with severe combined immunodeficiency. J Clin Invest 102:421-429

12. Katamura K, Tai G, Tachibana T, Yamabe H, Ohmori K, Mayumi M, Matsuda S, Koyasu S, Furusho K (1999) Existence of activated and memory CD4+ T cells in peripheral blood and their skin infiltration in CD8 deficiency. Clin Exp Immunol 115:124-130

13. Masternak K, Muhlethaler-Mottet A, Villard J, Peretti M, Reith W (2000) Molecular genetics of the Bare lymphocyte syndrome. Rev Immunogenet 2:267-282

14. Matsuda S, Suzuki-Fujimoto T, Minowa A, Ueno H, Katamura K, Koyasu S (1999) Temperature-sensitive ZAP70 mutants degrading through a proteasome-independent pathway. Restoration of a kinase domain mutant by Cdc37. J Biol Chem 274:34515-34518

15. Mazer B, Harbeck RJ, Franklin R, Schwinzer R, Kubo R, Hayward A, Gelfand EW (1997) Phenotypic features of selective $\mathrm{T}$ cell deficiency characterized by absence of CD8+ T lymphocytes and undetectable mRNA for ZAP-70 kinase. Clin Immunol Immunopathol 84:129-138

16. Miosge LA, Goodnow CC (2005) Genes, pathways and checkpoints in lymphocyte development and homeostasis. Immunol Cell Biol 83:318-335

17. Noraz N, Schwarz K, Steinberg M, Dardalhon V, Rebouissou C, Hipskind R, Friedrich W, Yssel H, Bacon K, Taylor N (2000) Alternative antigen receptor (TCR) signaling in $\mathrm{T}$ cells derived from ZAP-70-deficient patients expressing high levels of Syk. J Biol Chem 275:15832-15838

18. Rieux-Laucat F, Hivroz C, Lim A, Mateo V, Pellier I, Selz F, Fischer A, Le Deist F (2006) Inherited and somatic CD3zeta mutations in a patient with T-cell deficiency. N Engl J Med 354:1913-1921

19. Roifman CM, Hummel D, Martinez-Valdez H, Thorner P, Doherty PJ, Pan S, Cohen F, Cohen A (1989) Depletion of CD8+ cells in human thymic medulla results in selective immune deficiency. J Exp Med 170:2177-2182

20. Toyabe S, Watanabe A, Harada W, Karasawa T, Uchiyama M (2001) Specific immunoglobulin E responses in ZAP-70-deficient patients are mediated by Syk-dependent T-cell receptor signalling. Immunology 103:164-171

21. van Zelm MC, Reisli I, van der Burg M, Castaño D, van Noesel CJ, van Tol MJ, Woellner C, Grimbacher B, Patiño PJ, van Dongen JJ, Franco JL (2006) An antibody-deficiency syndrome due to mutations in the CD19 gene. N Engl J Med 354:1901-1912 